\title{
Evaluation the Impact of the Agricultural Activities on the Soil and Water: Case Study in Konya Province, Turkey
}

\author{
Nadire Üçler*, \\ Van Yuzuncu Yil University, Van Vocational School of Higher Education, Department of Construction Technology, Van, Turkey, (ORCID: 0000-0001-6407-121X), \\ nadireucler@yyu.edu.tr
}

(First received 25 June 2021 and in final form 28 August 2021)

(DOI: $10.31590 /$ ejosat.957724)

ATIF/REFERENCE: Üçler, N. (2021). Evaluation the Impact of the Agricultural Activities on the Soil and Water: Case Study in Konya Province, Turkey. European Journal of Science and Technology, (27), 243-250.

\begin{abstract}
As in many countries, Turkey's primary problem is the sustainable use of water resources. Agricultural activities not only affect the quantity of water but also quality. In this study, 2149 soil sample analysis reports were examined to evaluate the impact of agricultural activities on soil and water. Some important properties of soil have been investigated. Kruskal Wallis and Mann-Whitney tests were applied to examine whether there are significant differences between the phosphorus contents of the soil according to the districts and years. Different scenarios have been investigated to reduce the phosphorus $(\mathrm{P})$ concentration resulting from excessive fertilizer use. According to the results obtained, it was determined that safflower cultivation, which needs less fertilizer, and the use of ideal fertilizers can reduce the total $\mathrm{P}$ amount in half of the barley cultivation areas and half of the fallow areas.
\end{abstract}

Keywords: Water, Soil, Sustainability, Agricultural Activity, Pollution.

\section{Tarımsal Faaliyetlerin Toprak ve Su Üzerindeki Etkisinin Değerlendirilmesi: Konya İli, Türkiye Örneği}

Öz

Birçok ülkede olduğu gibi, Türkiye'nin de öncelikli sorunu, su kaynaklarının sürdürülebilir kullanımıdır. Tarımsal faaliyetler sadece suyun miktarını değil aynı zamanda kalitesini de etkiler. Bu çalışmada, tarımsal faaliyetlerin toprak ve su üzerindeki etkisini değerlendirmek için 2149 toprak numunesi analiz raporu incelenmiştir. Toprağın bazı önemli özellikleri araştırılmıştır. Toprağın fosfor içerikleri arasında ilçelere ve yıllara göre önemli farklılıklar olup olmadığını incelemek için Kruskal Wallis ve Mann-Whitney testleri uygulanmıştır. Fazla gübre kullanımından kaynaklanan fosfor (P) konsantrasyonunu azaltmak için farklı senaryolar incelenmiştir. Elde edilen sonuçlara göre arpa ekim alanlarının yarısında ve nadas alanlarının yarısında daha az gübre ihtiyacı olan aspir ekimi ve ideal gübre kullanımının toplam P miktarını azaltabileceği belirlenmiştir.

Anahtar Kelimeler: Su, Toprak, Sürdürülebilirlik, Tarımsal Faaliyet, Kirlilik.

\footnotetext{
* Corresponding Author: nadireucler@yyu.edu.tr
} 


\section{Introduction}

One of the most important parameters of sustainable watershed management is to identify pollutant sources and the appropriate strategy for the control of existing pollution. The fertilizers, herbicides and insecticides from agricultural lands and settlements can be listed among the main spread pollution sources. Nonpoint pollutants that reach high intensity cause degradation of the ecology and water quality of both underground and surface water sources. While the deterioration of ecological balance affects the vital activities of creatures living in these resources, the deterioration of water quality increases the costs of drinking water treatment and drinking water, recreation, etc. to disrupt the suitability for its intended use (Environment Agency, 2007; National Oceanic and Atmospheric Administration, 2008).

An increase in concentration of nutrients such as nitrogen $(\mathrm{N})$ and $\mathrm{P}$ in aquatic ecosystems may cause a problem called eutrophication (Nixon, 1996). The local watershed landscapes such as the soil, topography, and land use have intensely effects on the concentrations of $\mathrm{N}$ and $\mathrm{P}$ in waterbodies ( $\mathrm{Li}, 2020)$.

Plants need $\mathrm{P}$ which is the significant element for its growing and improvement. When the amount of phosphorus and organic matter is inadequate, fertilization is suggested to the cultivated plants (Bozyigit, 2020). Therefore, farmers tend to fertilize them during planting. And consequently, great ratio of $\mathrm{P}$ becomes inorganic in the soil which is cultivated and fertilized regularly (Dungait et al., 2012). After fertilization, a significant amount of $\mathrm{P}$ is either absorbed by soil or precipitated ( Blake et al., 2000). Also, high level of $\mathrm{N}$ applications which are above the crop need are possibly kept in the soil or gone to air or to water (Goulding et al., 2008). It is generally supposed that $5 \%$ of total $\mathrm{P}$ originated from fertilizers is received by the water body (Ozturk et al., 2007). Although small P losses from agriculture, it can be important for eutrophication of surface waters. (Johnston and Dawson, 2005).

Because of high level of nutrient concentrations, eutrophication is a significant problem in numerous Turkish river basins. In several studies conducted in Turkey, it was determined that the main cause of the formation of the P load resulted from agricultural activities (Ugurluoglu, 2009; Ozalp, 2009).

For these reasons, it has been thought that the evaluation of soil analysis reports of agricultural areas obtained from a province where intensive agricultural activities are carried out is important to understand the effects of agricultural activities on both soil and water resources. In this study, the current state of some important properties of the soil was determined by examining the analysis reports of 2149 soil samples in which different crops were planted between 2013 and 2015. Besides, predictions have been made about the change in the amount of $\mathrm{P}$ to be transported to water resources if different crops were planted or enough fertilizers were used.

\section{Material and Method}

\subsection{Study Area}

Konya province is in the south of Central Anatolia Region. Konya is geographically located between $36^{\circ} 41^{\prime}$ and $39^{\circ} 16^{\prime}$ north latitudes and $31^{\circ} 14^{\prime}$ and $34^{\circ} 26^{\prime}$ east longitudes. The total area is $41001 \mathrm{~km}^{2}$ and its average elevation is $1016 \mathrm{~m}$. There are mostly medium and large-scale agricultural enterprises in Konya, and it meets the requirement of the country in wheat, sugar beet, rye, bean, carrot, and legume production. Konya province has important lakes such as Lake Salt, Lake Beysehir and Lake Aksehir. With its wide plains such as Cihanbeyli Plateau and Obruk Plateau, it is a province that is qualified as the agricultural warehouse of Turkey (Ministry of Environment and Urbanization, 2018).

Lakes such as Lake Kulu Duden, Lake Salt and Lake Tersakan, where host water birds, are polluted as a result of the fertilizers and pesticides used in the agricultural areas surrounding them reaching the lake with surface water and precipitation into the lake. Because of these features, this province has been chosen as the study area. It is considered that the results obtained from these areas may reflect the impacts of the agricultural habits of country.

The soil analysis reports of 2149 soil samples belonging to agricultural areas (78 $520 \mathrm{da}$ ) in Cihanbeyli, Kulu and Altinekin districts were examined (Figure 1) (US Dept of State Geographer, 2020). These analysis reports were obtained from a laboratory where farmers conducted soil analysis to find out the amount of fertilizer required for the crops they planted. It is a certified laboratory inspected by the Ministry of Agriculture.

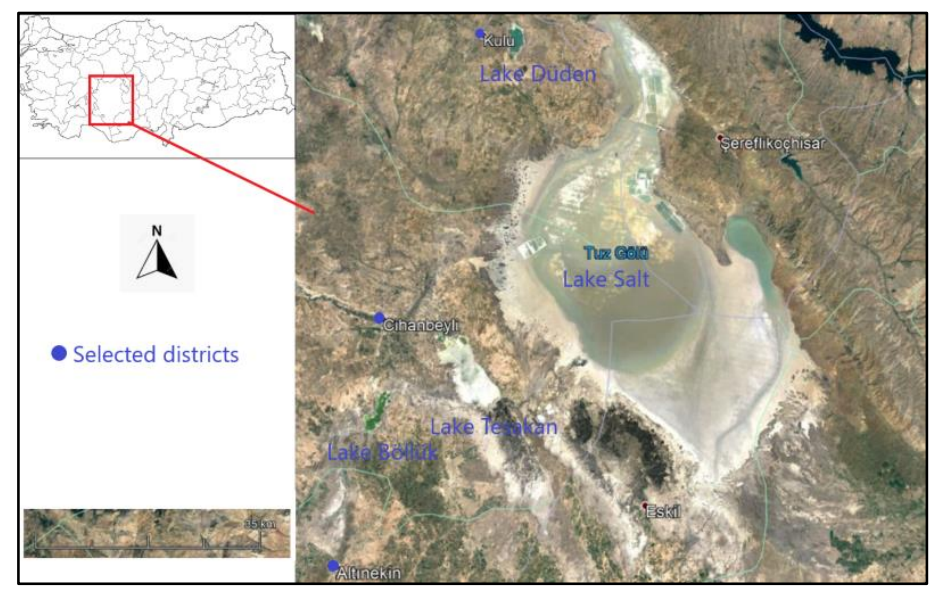

Figure 1. Study area

In this study, the following methods were used to determine whether the problem of excess fertilizer use is valid for the three districts and three years to which the samples belong.

\subsection{The Shapiro-Wilk Test}

The Shapiro-Wilk test is a test of normality was developed by Shapiro and Wilk in 1965 (Shapiro and Wilk, 1965).

The hypotheses are as below:

$\mathrm{H}_{0}$ : the data set is normally distributed.

$\mathrm{H}_{1}$ : the data set is not normally distributed.

If the $\mathrm{p}$ value is less than the chosen alpha level, then the $\mathrm{H}_{0}$ is rejected, and it is accepted that the data tested are not normally distributed. If the $\mathrm{p}$ value is greater than the chosen alpha level, the $\mathrm{H}_{0}$ cannot be rejected.

For this study alpha level was chosen as 0.05. For more information about test see Shapiro and Wilk (1965)

\subsection{Kruskal-Wallis Test}


European Journal of Science and Technology

The Kruskal-Wallis test was developed by Kruskal and Wallis in 1952 (Kruskal and Wallis, 1952). This test is a nonparametric test its aim to state whether all data sets are identical or at least one of the data sets have a tendency give observations that are different from those of other data sets. The Kruskal-Wallis test is applied if the data is not normally distributed, if the number of groups/conditions is three or more and different subjects are used in all groups/conditions.

The hypotheses are as below:

$\mathrm{H}_{0}$ : There is no difference between the data sets.

$\mathrm{H}_{1}$ : At least one of the data sets differs from the other data sets.

For more information about test see Kruskal and Wallis (1952).

\subsection{The Mann-Whitney $U$ test}

The Mann-Whitney U test is a nonparametric test and has a purpose in to determine if there are statistically significant differences between two data sets (Mann and Whitney, 1947).

The hypotheses are as below:

$\mathrm{H}_{0}$ : the distributions of both data sets are equal.

$\mathrm{H}_{1}$ : the distributions are not equal.

For more information about test see Mann and Whitney (1947).

\subsection{Strategy to Reduce to $P$ Amount}

How the proper fertilizer usage may affect the P level was examined using equations 1 and 2.

$Z_{P}=\frac{\sum_{i=1}^{n} X_{i} A_{i}-\sum_{i=1}^{n} Y_{i} A_{i}}{\sum_{i=1}^{n} X_{i} A_{i}} \cdot 100$

$W_{P}=\frac{\sum_{i=1}^{n} X_{i} A_{i}-\sum_{i=1}^{n} Y_{i} A_{i}}{\sum_{i=1}^{n} A_{i}}$

Here:

$\mathrm{Zp}$ : change in the total amount of $\mathrm{P}(\%)$

WP: change in total $\mathrm{P}$ amount per decare $\left(\mathrm{kg} \mathrm{da}^{-1}\right)$

n: number of samples

$\mathrm{X}$ : current $\mathrm{P}$ concentrations of soil samples $\left(\mathrm{kg} \mathrm{da}^{-1}\right)$

Y: ideal $\mathrm{P}$ concentrations for each crop $\left(\mathrm{kg} \mathrm{da}^{-1}\right)$

A: cultivation area (da)

Equations 3 and 4 were used to determine the effect of growing alternative crops on the amount of $\mathrm{P}$.

$T_{P}=\frac{B . C-(B+S) \cdot \frac{C}{2}}{B . C} \cdot 100$

$K_{P}=\frac{B \cdot C-(B+S) \cdot \frac{C}{2}}{\sum_{i=1}^{n} X_{i} A_{i}} \cdot 100$

Here:

$\mathrm{Tp}$ : change in the total amount of $\mathrm{P}$ based on the area in which the current crop was planted (\%)

Kp: change in the total amount of $\mathrm{P}$ based on all cultivated areas $(\%)$ $\left.\mathrm{da}^{-1}\right)$

B: mean P value of soil where current crop was planted $(\mathrm{kg}$
C: total cultivation area of current crop (da)
$\mathrm{n}$ : number of samples

$\mathrm{X}$ : current $\mathrm{P}$ concentrations of soil samples $\left(\mathrm{kg} \mathrm{da}^{-1}\right)$

$\mathrm{S}$ : P concentration of alternative crop $\left(\mathrm{kg} \mathrm{da}^{-1}\right)$

A: cultivation area (da)

\section{Results and Discussion}

Some important parameters will be examined in detail below according to the soil analysis reports of 2149 soil sample which belong to the three districts.

\subsection{Crops and Soil Type}

Figure 2 illustrates that the percentage of areas of crops cultivated on the soil in where these 2149 examples were taken. It is understood from reports that the main crops are wheat, sunflower, and barley, additionally it is seen that an important amount of area is left fallow.

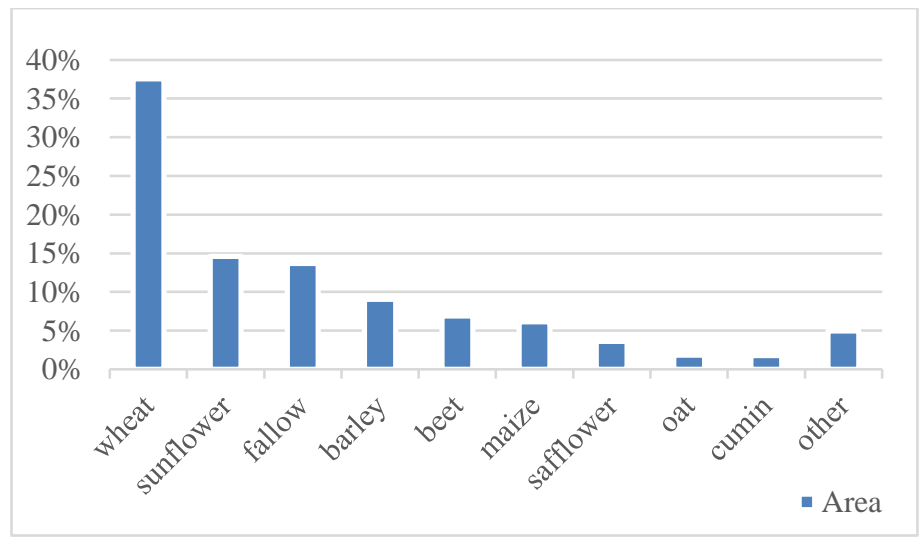

Figure 2. The evaluation of areas of crops

Figure 3 explains that the percentage of areas of dry and irrigated areas. Some reports do not have any explanation about cultivation method, so they are indicated as undefined. Although irrigated agriculture seems to have a higher percentage than dry agriculture, there is uncertainty in this regard due to samples with undefined status. Study area is more suitable for dry cultivation due to its climate. 


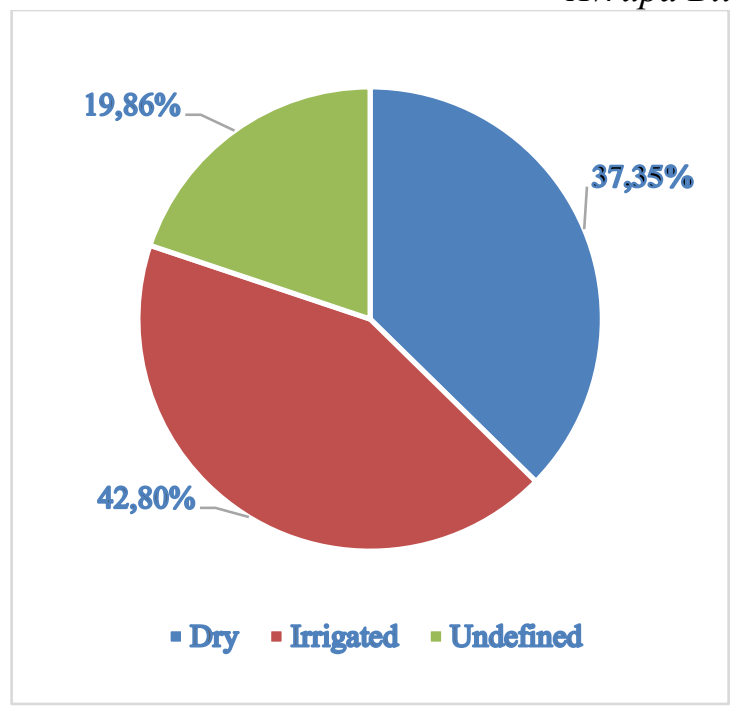

Figure 3. The evaluation of cultivation type

The percentages of soil type indicate that most of the samples are loam and clay loam soils (Figure 4).

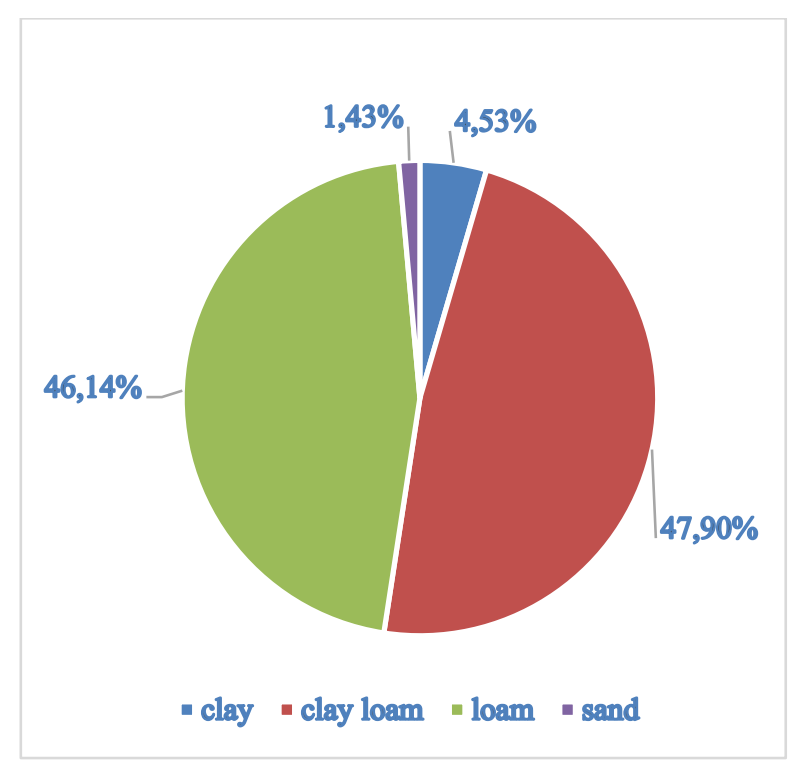

Figure 4. The evaluation of soil type

\subsection{Some Features of Soil}

The current situations of soil salinity, $\mathrm{pH}$ value (in water saturated soil), lime $\left(\mathrm{CaCO}_{3}\right)$, organic matter, $\mathrm{P}$ (from $\left.\mathrm{P}_{2} \mathrm{O}_{5}\right)$ and potassium $(\mathrm{K})$ (from $\mathrm{K}_{2} \mathrm{O}$ ) amounts were determined.

The $\mathrm{pH}$ shows the levels of acidity or basicity of the soil. These levels have such an important act in the digestion of nutrients by the plant. The $\mathrm{pH}$ level can be affected by different features such as the seasons, the water content, the type and temperature of soil, and the presence of a crop (Didon, 2015; Baiza, 2000). The soil of the study area is slightly alkaline with a mean of 8.36 and its standard deviation is 1.817 . The organic matter of the soil indicates the quality of the soil (Laudicina et al., 2015) owing to its positive effects on some features of soil such as stability and the water-holding capacity. The results show that the soils of the study area have a "medium level" of organic matter with $\% 2.11$, its standard deviation is 0.76 .

The general evaluation of $\mathrm{pH}$ and total organic matter can be seen in Figure 5 and Figure 6, respectively.

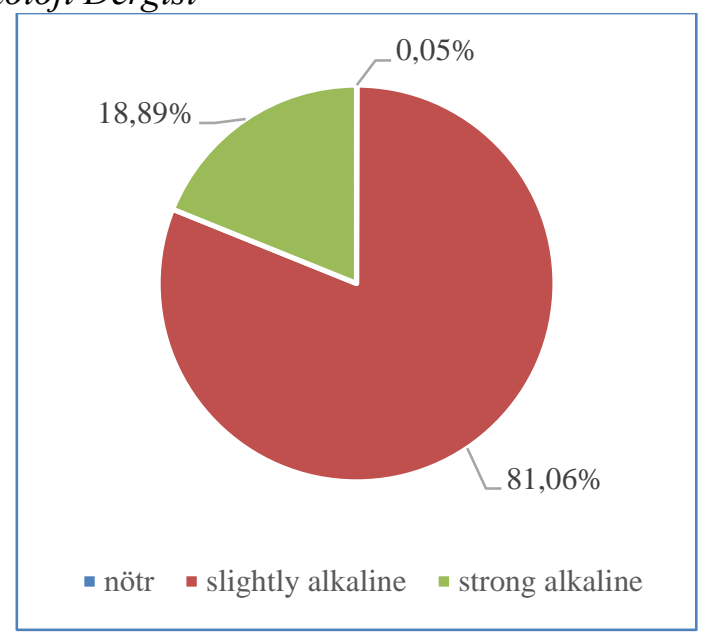

Figure 5. The evaluation of $p H$

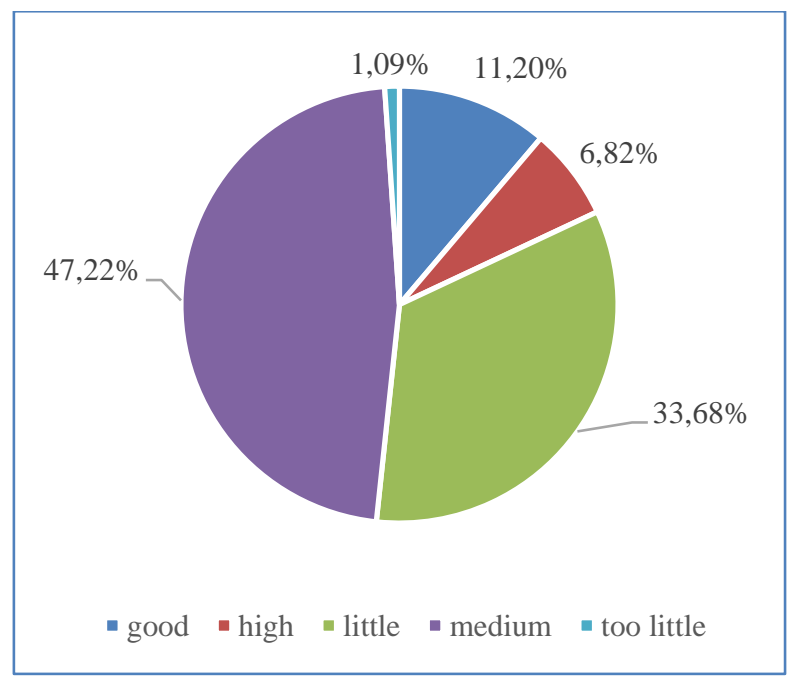

Figure 6. The evaluation of organic matter

According to the results, some samples have high level of salt contents like $62.55 \%$ which has been increasing the average of salt level to $0.84 \%$ although more than $97 \%$ of soil are characterized without salt.

The mean $\mathrm{K}$ value of the soil examples is $322.90 \mathrm{~kg} \mathrm{da}^{-1}$ and this result shows that these areas are rich in $\mathrm{K}$. Maximum $\mathrm{K}$ value is $3134.97 \mathrm{~kg} \mathrm{da}^{-1}$ and its standard deviation is $262.84 \mathrm{~kg} \mathrm{da}^{-1}$ which indicates there are unnecessary $\mathrm{K}$ fertilization. The unnecessary amount of the $\mathrm{K}$ may change to salt and cause deficiencies of $\mathrm{Mg}, \mathrm{Ca}, \mathrm{B}, \mathrm{Zn}, \mathrm{Mn}$ for crops, which affects the quality negatively. They can easily contaminate groundwater through percolation and infiltration.

General evaluation of the $\mathrm{P}$ contents of the soil, which has the major effects on the contamination of the water resources, are showed that above $55 \%$ of the soils are qualified by a "too much", $20.88 \%$ "excess" and almost $8 \%$ of them not have enough P. It can be understood from Figure 7, only $15.47 \%$ of them are characterized by "enough". Therefore, it can be understood easily, there is not any standard about using phosphorus-containing fertilizer. It also points to the use of fertilizers beyond measure to increase productivity. 


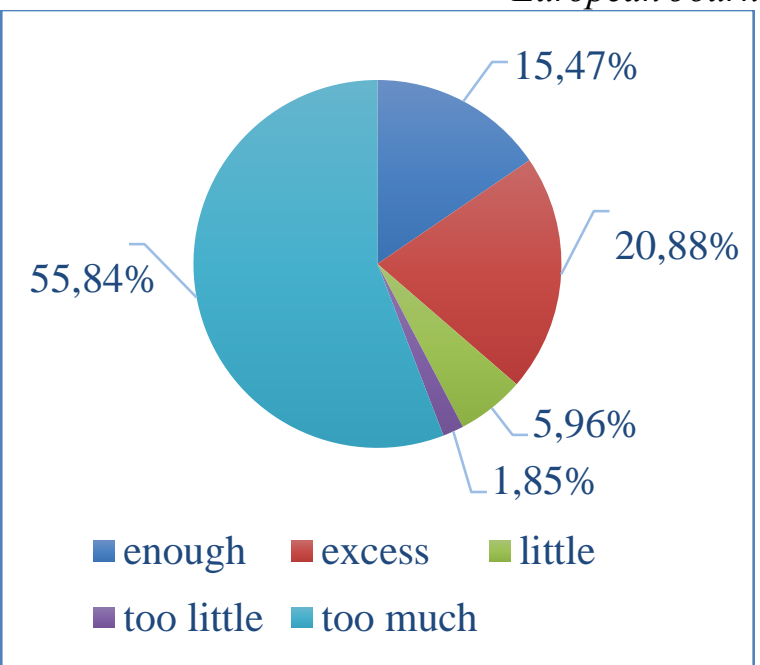

Figure 7. The evaluation of $P$

Figure 8 and 9 show variations of $\mathrm{P}$ concentrations $\left(\mathrm{kg} \mathrm{da}^{-1}\right)$ at districts and years, respectively.

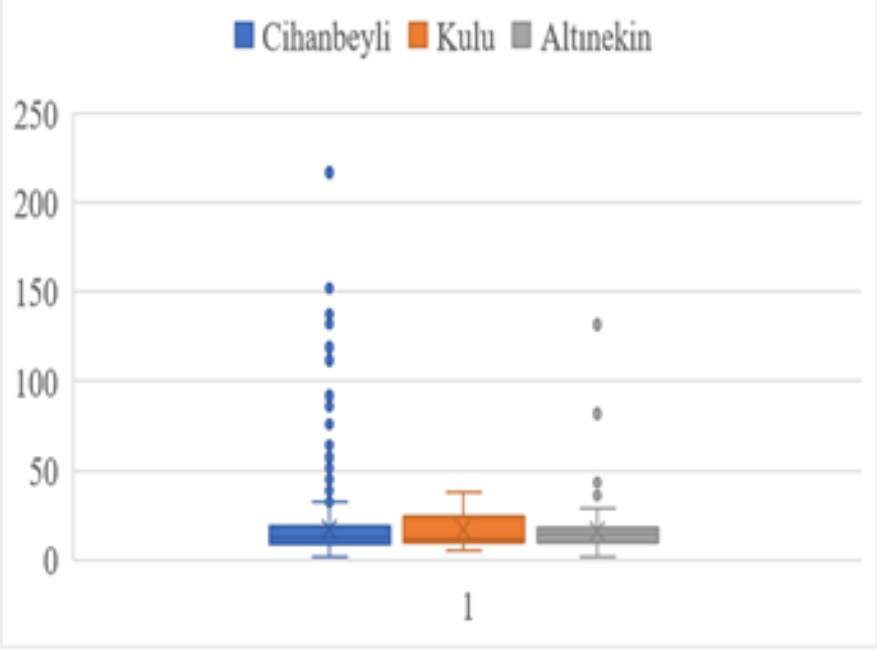

Figure 8. Variations of $P$ concentration at districts

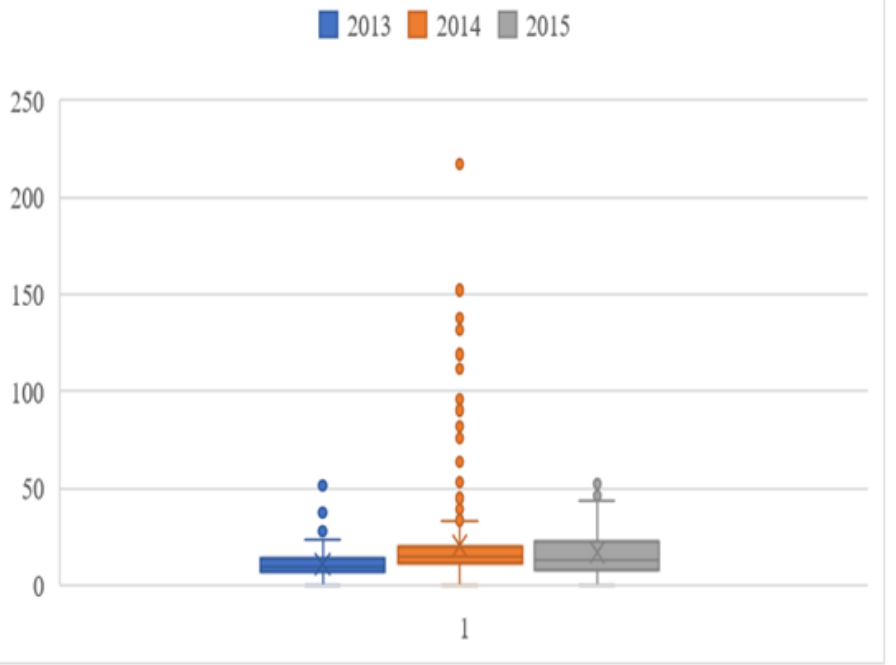

Figure 9. Variations of $P$ concentration at years

It is necessary to check the normality of the data sets to determine whether the phosphorus concentrations show significant changes according to the districts and years. Therefore, firstly, it was determined whether the dataset has normal distribution or not.

\subsection{Shapiro-Wilk Test Results}

The distribution of the phosphor amount of soil was detected by the Shapiro-Wilk test. Since D $(2149)=0.054$ and $p=0.000<$ 0.05 (significance level) it can be understood that the data set do not distributed normally (see histogram of $\mathrm{P}$ in Figure 10).

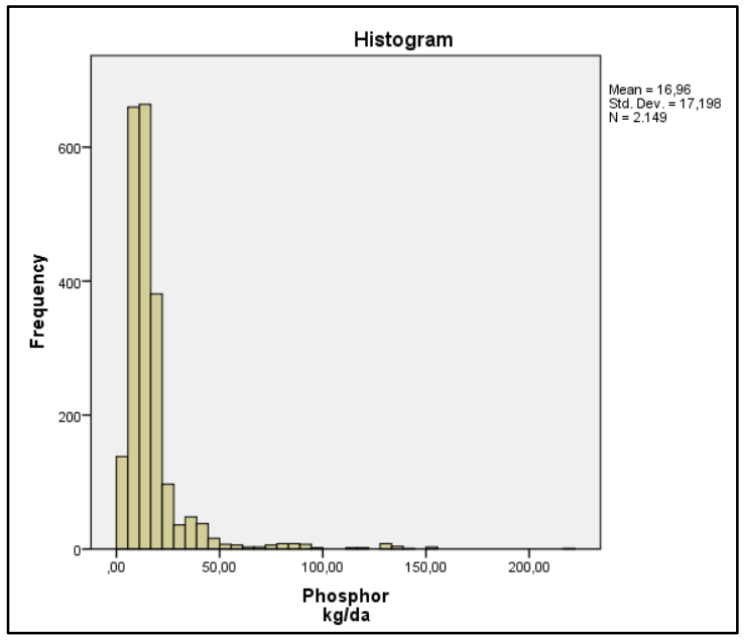

Figure 10. The histogram of the $P$

\subsection{Kruskal-Wallis Test Results}

Since data set do not fulfill the normal distribution condition, a nonparametric test called Kruskal-Wallis test was used to test the null hypothesis that data sets have equal distribution functions versus to the alternate hypothesis that at least two of the data sets have different distribution functions.

In the relation "phosphor amount of soil versus province", $p$ value is equal to 0.882 , with Chi-squared equal to 0.251 and degrees of freedom equal to 2 . Since $\mathrm{p}$ value was higher than the significance level 0.05 , it is assumed that there are no significant differences between phosphor amount of soil on the subject to province. These results indicate that the problem of excess fertilizer use is valid for all three districts.

In the relation "phosphor amount of soil versus years", $p$ value is equal to 0.000 , with Chi-squared equal to 363.174 and degrees of freedom equal to 2 . Since $p$ value was lower than the significance level 0.05 , it is assumed that at least two of the data sets have different distribution functions on the subject to years.

\subsection{Mann Whitney U Test Results}

Mann Whitney U test was applied to the data for 2013 and 2014, 2013 and 2015 and 2014 and 2015 to find out between which years there was a significant difference. Since each has its own alpha error percentage $(\alpha)$, Bonferroni correction is made and the value of 0.05 is divided into three and the $p$ value is compared with 0.0167 . If $p$ is lower than the 0.0167 , the hypothesis which assumes that there is a meaningful difference between two years is accepted. According to the results of test, there is a significant difference between the P concentrations of 2013 and $2014(\mathrm{U}=$ 
$254065.50 \mathrm{p}=0,000<0.0167, \mathrm{z}=-19.104, \mathrm{r}=-0.41)$. Since the effect coefficient $r=-0.41$ is close to 0.5 , the effect coefficient is considered large. Similarly, a significant difference was found between 2013 and 2015. ( $\mathrm{U}=14280 \mathrm{p}=0,000<0.0167, \mathrm{z}=$ $3.591, r=-0.12$ ). The effect coefficient $r=-0.12$ is considered small. The result of the test of 2014 and 2015 showed that there is not a significant difference in $\mathrm{P}$ concentrations between these years $(U=29791 \mathrm{p}=0,054>0.0167, \mathrm{z}=-1.928, \mathrm{r}=-0.051)$.

The mean rank values of 2013 and 2014 (715.05 and 1239.76 respectively) and the mean rank values of 2013 and 2015 (401.19 and 521.54 respectively) showed that the P concentrations in 2014 and 2015 were higher than 2013.

The fact that the data belonged to 5 years ago may suggest that the detected problem may have been outdated, but reports show that there has been no decreasing in the amount of using phosphorus-containing fertilizers since 2013. According to the Provincial Environmental Status Reports for 2013 and 2018, the amount of $\mathrm{P}$ used on the basis of plant nutrients increased by $37.08 \%$, while the increase in the total area cultivated using commercial fertilizers in the province was $16.27 \%$ between these years (Ministry of Environment and Urbanization 2013; Ministry of Environment and Urbanization 2018). Thus, we can say that excessive and unconscious fertilizer use is still a current problem.

\subsection{Current and Ideal Fertilizer Comparison}

It was examined that the appropriate fertilizer usage how could affect the level of $\mathrm{P}$ which could reach to the water resources. The $\mathrm{P}$ values according to the fertilizer which most cultivated crops require were assigned utilizing the amount of $\mathrm{P}_{2} \mathrm{O}_{5}$ used for each crop per year / per decare (Kacar and Katkat, 1997). Current mean $P$ values, ideal $P$ values and cultivated areas are given in Table 1. The possible change of $\mathrm{P}$ amount can be seen based on products and in total in Figure 11. The results showed that if ideal fertilizer is used, the total amount of $\mathrm{P}$ can decrease by $46 \%$. Considering the study area of $78520 \mathrm{da}$, this change was calculated as $7.70 \mathrm{~kg}$ per decare.

Table 1. Current mean $\mathrm{P}$ values, ideal $\mathrm{P}$ values and cultivated areas

\begin{tabular}{lccc}
\hline $\begin{array}{l}\text { Crop } \\
\text { Type }\end{array}$ & $\begin{array}{c}\text { Current Mean P } \\
\left(\mathrm{kg} \mathrm{da}^{-1}\right)\end{array}$ & $\begin{array}{c}\mathrm{P} \\
\left(\mathrm{kg} \mathrm{da}^{-1}\right)\end{array}$ & $\begin{array}{c}\text { Area } \\
(\mathrm{da})\end{array}$ \\
\hline $\begin{array}{l}\text { wheat } \\
\text { dry }\end{array}$ & 16.28 & 5.50 & 11596.80 \\
\hline $\begin{array}{l}\text { wheat } \\
\text { irrigated }\end{array}$ & 16.19 & 7.00 & 11464.60 \\
\hline $\begin{array}{l}\text { wheat } \\
\text { undefined }\end{array}$ & 17.45 & 6.25 & 6627.80 \\
\hline barley & 21.32 & 6.50 & 6964.53 \\
\hline beet & 14.30 & 6.50 & 5436.10 \\
\hline sunflower & 13.97 & 6.50 & 11529.66 \\
\hline maize & 16.27 & 5.50 & 4710.00 \\
\hline safflower & 12.66 & 4.00 & 2847.66 \\
\hline oat & 14.24 & 6.00 & 1457.23 \\
\hline cumin & 16.66 & 6.50 & 1401.55 \\
\hline
\end{tabular}

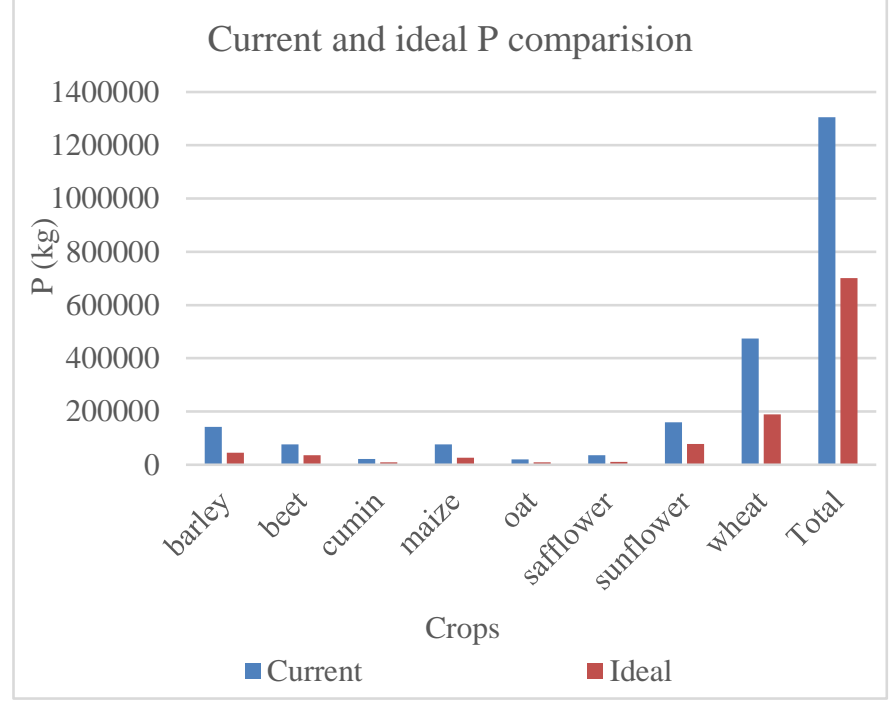

Figure 11. The possible change of the P amount

\subsection{Different Product Suggestion}

A different scenario was applied to determine that the cultivation of a different product which needs less fertilizer how may affect the contamination level of the water resources. For this purpose, safflower was determined as alternative product due to its some important features.

Colorful flowers of safflower are used in food and fabric dye. Safflower oil is good quality as edible oil and can also be used in biodiesel production. Also, its pulp can be considered as animal feed (Babaoglu, 2006a). All the tools and equipment used in wheat-barley agriculture can also be used in the agriculture of this plant. Furthermore, the Ministry of Agriculture thinks that safflower agriculture should be expanded in our country to meet our edible oil needs and to produce biodiesel from vegetable oils. It is also emphasized by the Ministry that it is a plant that can be grown in almost every part of our country, especially in idle areas, due to its drought resistance. In addition, it is stated that every plant that processes sunflower in our country will be able to easily process safflower seeds into oil without using any additional machinery, without making any changes (Babaoglu, 2006b). For this reason, when safflower is grown instead of barley, it is thought that there will be no economic loss.

Hence, a different scenario was tried out to decrease the pressure on water source and change in the total amount of $\mathrm{P}$ was examined in the event of planting the safflower instead the barley, requires more $P$ fertilizers than safflower and used same planting equipment as safflower while cultivating. The results to be obtained when planting safflower by using ideal fertilizer in half of the area where barley cultivation is made in 6964.53 decare can be seen from Table 2 . Total amount of $P$ caused by barley land has decreased by $40.62 \%$ and it has been $4.62 \%$ the reflection of this decrease to the general amount of $\mathrm{P}$. 
European Journal of Science and Technology

Table 2. Possible change of $P$ amount when safflower with ideal fertilizer is planted in half of the barley field

\begin{tabular}{lccl}
\hline Product & $\begin{array}{l}\text { Mean } \\
\left(\mathrm{kg} \mathrm{da}^{-1}\right)\end{array}$ & $\begin{array}{l}\text { Total } \\
(\mathrm{da})\end{array}$ & $\begin{array}{l}\text { Total } \\
(\mathrm{kg})\end{array}$ \\
\hline barley & 21.32 & 6964.53 & 148471.01 \\
$\downarrow$ & 21.32 & 3482.27 & 74235.50 \\
barley & 4.00 & 3482.27 & 13929.07 \\
safflower & & 40.62 \\
\% decrease in total amount of P in barley land & 4.62 \\
\hline
\end{tabular}

Possible changes in the amount of $\mathrm{P}$ when ideal amount of fertilizer is used in both barley and safflower are given in Table 3. The reduction in the amount of $\mathrm{P}$, which is $40 \%$ if the ideal fertilizer is only used in safflower cultivation, has reached $75 \%$ when the ideal amount of fertilizer is used in both products. The effect of this decrease to the total amount of $\mathrm{P}$ is 8.57.

Table 3. Possible change of $P$ amount when both safflower and barley are planted with ideal fertilizer

\begin{tabular}{lccl}
\hline Product & $\begin{array}{l}\text { Mean } \\
\left(\mathrm{kg} \mathrm{da}^{-1}\right)\end{array}$ & $\begin{array}{l}\text { P Total } \\
(\mathrm{da})\end{array}$ & $\begin{array}{l}\text { Area } \\
(\mathrm{kg})\end{array}$ \\
\hline barley & 21.32 & 6964.53 & 148471.01 \\
$\downarrow$ & & & \\
barley & 6.50 & 3482.27 & 22634.73 \\
safflower & 4.00 & 3482.27 & 13929.07 \\
\% decrease in total amount of P in barley & 75.37 \\
land & & 8.57 \\
\% decrease in general amount of P & \\
\hline
\end{tabular}

In addition, $40.10 \%$ decrease in total amount of $\mathrm{P}$ in the case of cultivation of safflower by using ideal fertilizer in half of the fallow lands that have high $\mathrm{P}$ content as a result of excessive fertilization during the cultivation period can be seen in Table 4. This declining affects the total amount of $\mathrm{P}$ by $6.71 \%$.

Table 4. Possible change of $P$ amount when safflower with ideal fertilizer is planted in half of the fallow field

\begin{tabular}{llll}
\hline Product & $\begin{array}{l}\text { Mean } \\
\mathrm{P} \\
\left(\mathrm{kg} \mathrm{da}^{-1}\right)\end{array}$ & $\begin{array}{l}\text { Total } \\
\text { Area } \\
(\mathrm{da})\end{array}$ & $\begin{array}{l}\text { Total P } \\
\text { from Fallow } \\
(\mathrm{kg})\end{array}$ \\
\hline $\begin{array}{lll}\downarrow \\
\text { fallow }\end{array}$ & 10813.46 & 218406.75 \\
fallow & 20.20 & & \\
safflower & 4.00 & 5406.73 & 109203.38 \\
\% change in total amount of P in fallow land & 40.10 \\
\% decrease in general amount of P & 6.71 \\
\hline
\end{tabular}

\section{Conclusions and Recommendations}

Turkey has different land structures in different regions. Therefore, the soil structure should be well known in order to determine the type of product that can be grown in the region with maximum efficiency. It is necessary to raise the awareness of farmers about whether soil properties are suitable for the product grown. Moreover, farmers should be informed to prevent the negativities in the soil caused by wrong practices.

Results showed that unconscious excess fertilizer is used during planting. While chemical fertilizer causes significant increases in agricultural production, on the other hand, it causes environmental problems arising from agricultural production. To change this case, knowledge of producers about appropriate planting, sufficient fertilization, spraying and irrigation should be increased. The use of organic fertilizers should be expanded and the development and use of fertilizer varieties suitable for country conditions should be encouraged.

In Turkey, owing to lack of research of alternate agricultural products for the market and uncertainty in crop prices, the farmers, with the penetration of habit, prefer to cultivate crops which the government gives the guarantee of market. For this reason, by choosing a product that is compatible with farmer habits and without economic losses, the positive effect on water resources has been investigated. Results showed that cultivation of an alternative crop with appropriate fertilization can decrease the $\mathrm{P}$ amount which will reach the water resources with surface water and precipitation.

\section{Acknowledge}

The data used in this study is obtained from a certified laboratory inspected by the Ministry of Agriculture.

\section{References}

Babaoğlu, M. (2006a). Safflower plant and cultivation. Technical report, Republic of Turkey Ministry of Agriculture and Forestry Directorate of Trakya Agricultural Research Institute.

https://arastirma.tarimorman.gov.tr/ttae/Sayfalar/Detay.aspx ?SayfaId=59 (Accessed 1 March 2020).

Babaoğlu, M. (2006b). History of the safflower plant in the world and Turkey, Uses and Its Importance. Technical report, Republic of Turkey Ministry of Agriculture and Forestry Directorate of Trakya Agricultural Research Institute. https://arastirma.tarimorman.gov.tr/ttae/Sayfalar/Detay.aspx ?SayfaId=58 (Accessed 1 March 2020)

Baize, D. (2000). Guide des analyses a pedology: choix, expression, presentation, interpretation. 2e ed, INRA- Paris.

Blake, L., Mercik, S., Koerschens, M., Moskal, S., Poulton, P. R., Goulding, K. W. T., ... \& Powlson, D. S. (2000). Phosphorus content in soil, uptake by plants and balance in three European long-term field experiments. Nutrient Cycling in Agroecosystems, 56(3), 263-275.

Bozyiğit, R. (2020). Seydikemer ilçesi (Muğla) topraklarının özellikleri ve kullanımı üzerine bir değerlendirme. Avrupa Bilim ve Teknoloji Dergisi, (18), 695-706.

Dinon, E. (2015). Gerstmans. African Crop Science Journal, 23, 101-111. 


\section{Avrupa Bilim ve Teknoloji Dergisi}

Dungait, J. A., Cardenas, L. M., Blackwell, M. S., Wu, L., Withers, P. J., Chadwick, D. R., ... \& Goulding, K. W. (2012). Advances in the understanding of nutrient dynamics and management in UK agriculture. Science of the Total Environment, 434, 39-50.

Environment Agency, (2007) Diffuse water pollution in England and wales report. Technical report, Foundation for Water Research.

http://www.fwr.org/WQreg/Appendices/EA_Diffuse_Pollution Report_geho0207bzlvee_1773088.pdf (Accessed 1 March 2020).

Goulding, K., Jarvis, S., \& Whitmore, A. (2008). Optimizing nutrient management for farm systems. Philosophical Transactions of the Royal Society B: Biological Sciences, 363(1491), 667-680.

Johnston, A. E., \& Dawson, C. J. (2005). Phosphorus in agriculture and in relation to water quality. Agricultural Industries Confederation.

Kacar, B., Katkat, V. (1997) Phosphorous in Agriculture. 2nd ed., Bursa Chamber of Commerce Publications, Bursa. (in Turkish)

Kruskal, W. H., \& Wallis, W. A. (1952). Use of ranks in onecriterion variance analysis. Journal of the American statistical Association, 47(260), 583-621.

Laudicina, V. A., Novara, A., Barbera, V., Egli, M., \& Badalucco, L. (2015). Long-term tillage and cropping system effects on chemical and biochemical characteristics of soil organic matter in a Mediterranean semiarid environment. Land Degradation \& Development, 26(1), 45-53.

Li, N. X., Xu, J. F., Yin, W., Chen, Q. Z., Wang, J., \& Shi, Z. H. (2020). Effect of local watershed landscapes on the nitrogen and phosphorus concentrations in the waterbodies of reservoir bays. Science of The Total Environment, 716, 137132.

Mann, H. B., \& Whitney, D. R. (1947). On a test of whether one of two random variables is stochastically larger than the other. The annals of mathematical statistics, 50-60.

Ministry of Agriculture and Forestry (2018). Fertilizer Sector Policy Document 2018-2022.

https://www.tarimorman.gov.tr/TAGEM/Belgeler/yayin/G\%C3 \%BCbre\%20Sekt\%C3\%B6r\%20Politika\%20Belgesi\%2020 18-2022.pdf. (Accessed 1 March 2020).

Ministry of Environment and Urbanization (2013). Konya provincial environmental status report. https://webdosya.csb.gov.tr/db/ced/editordosya/Konya_icdr2 013.pdf. (Accessed 10 March 2020).

Ministry of Environment and Urbanization (2018). Konya provincial environmental status report. https://webdosya.csb.gov.tr/db/ced/icerikler/konya_cdr_2018_rev-ze-20190808113124.pdf. Accessed 10 March 2020.

National Oceanic and Atmospheric Administration (2008). Nonpoint Source Pollution: Pollutants from Nonpoint Sources: Nutrients.

https://oceanservice.noaa.gov/education/kits/pollution/04nonpoi ntsource.html (Accessed 1 July 2019).

Nixon, S. W., Ammerman, J. W., Atkinson, L. P., Berounsky, V. M., Billen, G., Boicourt, W. C., ... \& Seitzinger, S. P. (1996). The fate of nitrogen and phosphorus at the land-sea margin of the North Atlantic Ocean. Biogeochemistry, 35(1), 141-180.

Ozturk, I., Tanik, A., Cokgor, E., Gurel, M., Mantas, E., Insel, G., \& Ozabali, A. (2007). Watershed protection action plan, final report, Greater Istanbul Water Supply Melen System II. Stage Buyuk Melen Watershed integrated protection and water management master plan, Istanbul Technical University. Environmental Engineering Department, Istanbul.

Ozalp, D. (2009). Determination of Diffuse Pollutant Sources and Management Recommendations in The Eastern Black Sea Basin. Thesis, Istanbul Technical University, Istanbul, Turkey.

Shapiro, S. S., \& Wilk, M. B. (1965). An analysis of variance test for normality (complete samples). Biometrika, 52(3/4), 591611.

Ugurluoğlu, A. (2009). Estimation of N and P Loads Coming from Distributed Sources to Water Sources in Case of Limited Data: Example of Çoruh Basin. Thesis, Istanbul Technical University, Istanbul, Turkey.

US Dept of State Geographer (2020). Google Image Landsat/Copernicus, Data SIO, NOAA. US Navy, NGA GEBCO 